\section{Lino Cabezas}

Departamento de Dibujo Universidad de Barcelona Diagonal Sud

Facultat de Belles Arts Pau Gargallo, 4 08028 Barcelona SPAIN linocabezas@ub.edu

Keywords: perspective theory, Pedro Berruguete, Juan Bautista Villalpando, vaults, coffered ceilings, Renaissance architecture, ornamentation

\section{Ornamentation and Structure in the Representation of Renaissance Architecture in Spain}

Presented at Nexus 2010: Relationships Between Architecture and Mathematics, Porto, 13-15 June 2010.

Abstract. In the Renaissance, geometric perspectives became a method of architectural reasoning. We look at two works: a painting attributed to Pedro Berruguete and an engraving by Juan Bautista Villalpando in order to to discover the complex relationship between geometry and architecture, and in particular, the form of representation. Our analysis is based on the idea that geometric perspective meant architecture of the period was capable of graphically controlling reality through a high degree of geometric precision.

Images are often the most important references for the discovery of relations between geometry and architecture. Some images may attain extraordinary prominence and acquire total autonomy, even becoming the centre of attention in aesthetic debates and when formulating theories in general. Using images from different historical situations, it is possible to discover many aspects related to architecture.

In the case of images of architecture from the beginning of the Modern Era, this is easy to understand: at that time, the culture of Disegno was at its peak in the history of art, in parallel with the construction of a science of representation and the appearance of a new art form driven by artists' thirst for invention.

In this Renaissance setting, the formulation of geometric perspectives was of major importance, and its use in architecture caused a revolution with clear results, even though they have not always been considered good. The architect Bruno Zevi, recognising its significance, gave a very negative evaluation of the consequences of this visual culture of perspective. In II linguaggio moderno dell' architettura, he wrote:

In the early fifteenth century disaster struck. It was the triumph of perspective. Architects stopped worrying about architecture, and just drew

it. The damage was enormous, increased over the centuries and continues to grow with industrialised construction [Zevi 1973; our trans.].

While the words of Zevi are conditioned by the historic circumstances of his time, they serve to illustrate a debate in which favourable opinions on perspective are more numerous. For many, since the Renaissance, in addition to being the expression of a powerful visual conception of the arts, perspective has become a method for architectural reasoning. This is like the species dispositionis concept of the Roman architect Vitruvius, who, in the first century B.C., defined perspective (scenographia), together with the floor plan (ichnographia) and elevation (ortographia), as three kinds of architectural arrangement, and not just a simple graphic system to represent it.

Before focussing on the analysis of architecture represented in perspective, we are aware of the difficulty in indiscriminately applying the term 'image' to all representations of architecture. According to René Huyghe [1965], our culture has evolved from the 'Civilisation of the book' into the 'Civilisation of the image'. For this reason, we 
highlight our interest in one of the special functions of images in architecture, that which is conditioned or directed towards its graphic control, to resolve the geometry.

Geographically and chronologically, we focus on architecture in Spain around the sixteenth century. We look at two works: a painting attributed to Pedro Berruguete (fig. 1), dating back to the end of the fifteenth century, and an engraving by Juan Bautista Villalpando (fig. 2), from the end of the sixteenth century. Our interest in both is to discover the complexity of the relationship between geometry and architecture, and in particular, the form of representation.

In the hundred years which separate the two works, there were major changes not only in architecture and the theoretical development of geometry of form, but also major transformations in design approaches and the construction techniques used during this, the sixteenth, century.

In the painting we focus our attention on the Mudejar coffered ceiling of the chapel, while in the engraving we are interested in the groin vault, decorated with rhomboidal coffering. The images have in common a visual conception of architecture, demonstrated by the geometric perspective which would mature scientifically in Europe during the sixteenth century, with contributions from important writers such as Viator [1505], Dürer [1525], Serlio [1545] and Vignola [1583] (fig. 3).

In the panel of Pedro Berruguete, different formal and stylistic elements of the time can be identified. The architectonics of the composition has a perspective which gives a natural feeling to a chapel which takes centre stage for its appearance of reality. The confluence of traditions in this is clear, at a time which contemporary history describes a Spain in transition from Hispano-Flemish art to painting in line with the postulates of Italian art.

The similarities of the Gothic fretwork to a panel by Rogier van der Weyden are evident, continuing with tradition (fig. 4). The Gothic elements contrast stylistically with the lateral semi-circular arches and the pseudo-Corinthian capitals which support them. It was painted at a time when Gothic forms coexisted with the new Renaissance models; under these circumstances, the ability to integrate different styles was considered a professional merit which many artists could boast of. Despite this, the new 'Roman' Renaissance repertoires, written about in detail, circulated and were imposed, demanding a purity of style incompatible with previous forms. In 1526, in the first treatise on art printed in Spain, its author, Diego de Sagredo, condemns those conceited enough to boast of their ability to mix the new Renaissance repertoires with the Gothic tradition which was still alive and which he wanted to overthrow: "And take care not to presume to mix Roman with modern [i.e., Gothic]” [Sagredo 1526: iiii r].

Leaving aside the clash between Gothic and Renaissance, latent in the panel, the presence of a Mudejar ceiling is the most remarkable feature of the painting. This element is of a firmly seated typology of the time, in line with the abundance of these wooden structures in architecture in most of the Iberian peninsula.

Our analysis is based on the idea that geometric perspective meant architecture of the period was capable of graphically controlling reality through a high degree of geometric precision. However, examining the graphic precision of the painting attributed to Berruguete, there is a contradiction between the low level of geometric precision in the spatial construction of the chapel and the higher level in the work on the coffered ceiling (fig. 5). 


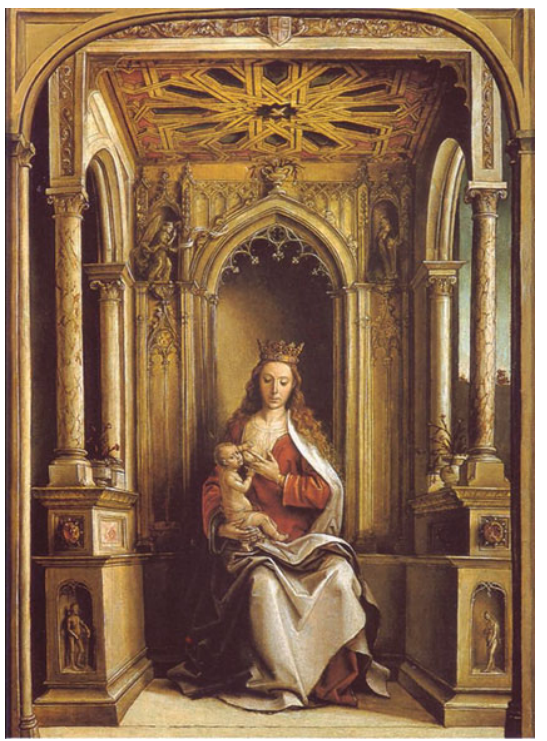

Fig. 1. Pedro Berruguete, Virgen con el niño. Madrid. Museo Municipal

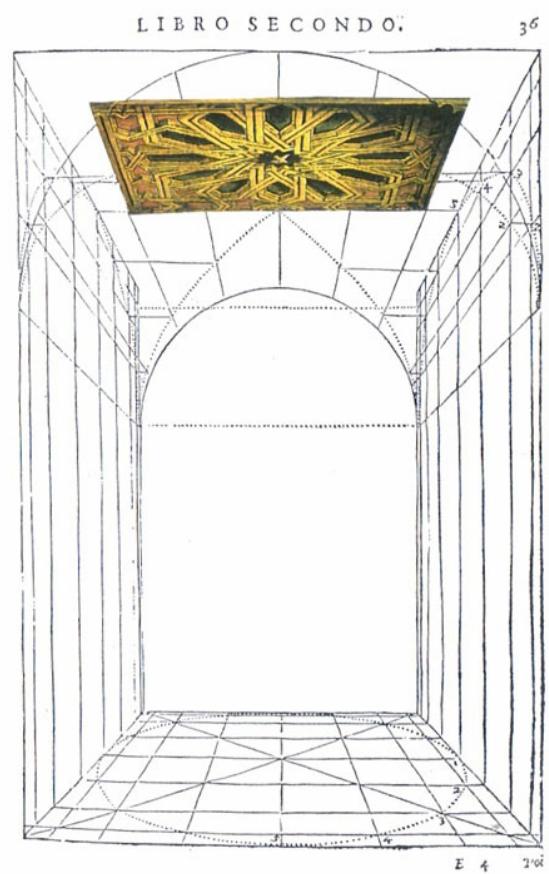

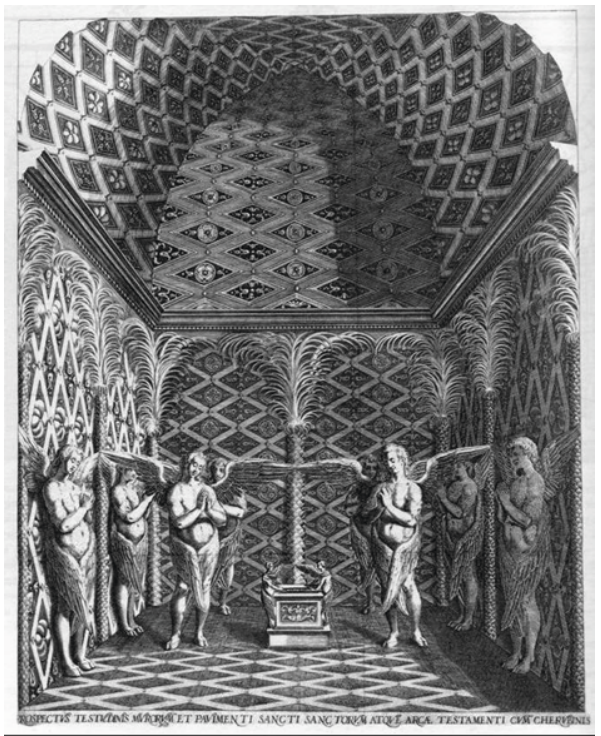

Fig. 2 Juan Bautista Villalpando, perspective of the inside of the Holy of Holies, In Ezechielem Explanaciones, 1595

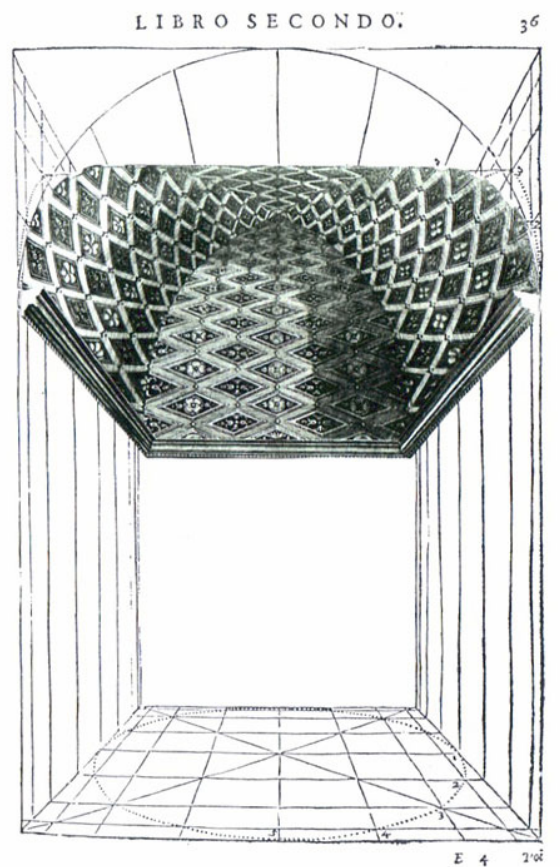

Fig. 3. Photomontage of the works analysed and the engraving from Sebastiano Serlio, Libro de perspectiva, 1545 


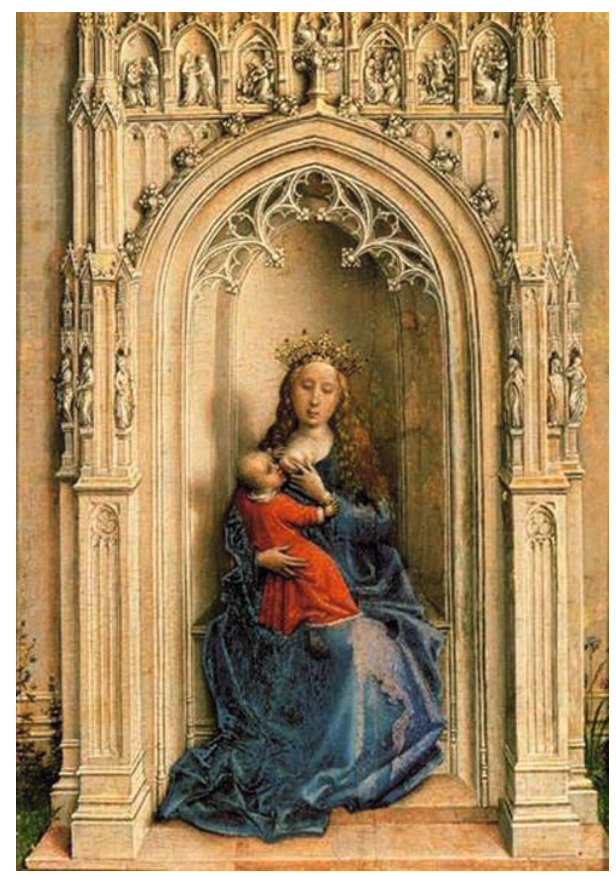

Fig. 4. Rogier Van der Weyden, La Virgen con el Niño entronizada. Museo Thyssen- Bornemisza, Madrid
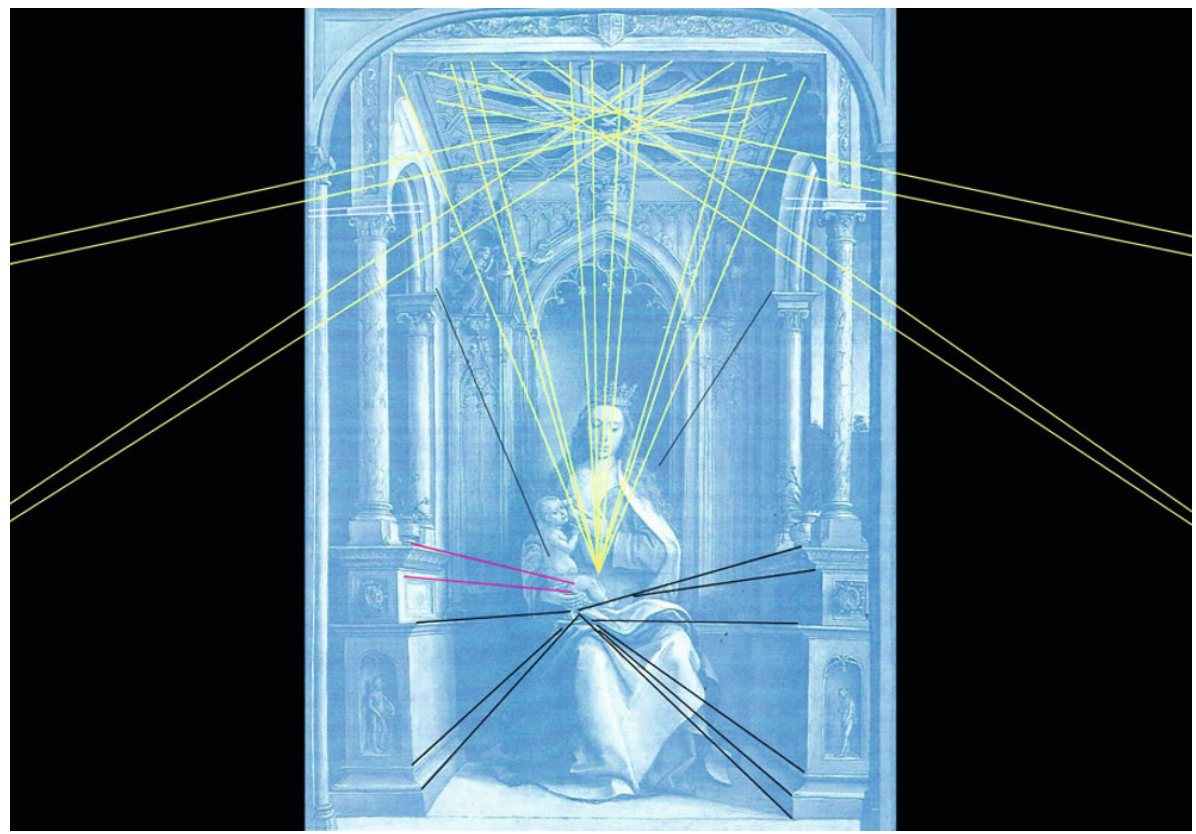

Fig. 5. Geometric analysis of the perspective in the panel by Pedro Berruguete 
The painting is a small panel kept in the Madrid Municipal Museum. The importance of Pedro Berruguete is rooted in having been identified by art critics and historians as marking the transition to a period of great art in Spain that would reach its peak in the seventeenth century, the Golden Age of Spanish painting. His role in introducing a new Italianised style, far removed from Flemish models, was made possible, according to certain critics, by a supposed stay in Urbino, working for the duke and in contact with Piero della Francesca and Francesco di Giorgio Martini. ${ }^{1}$

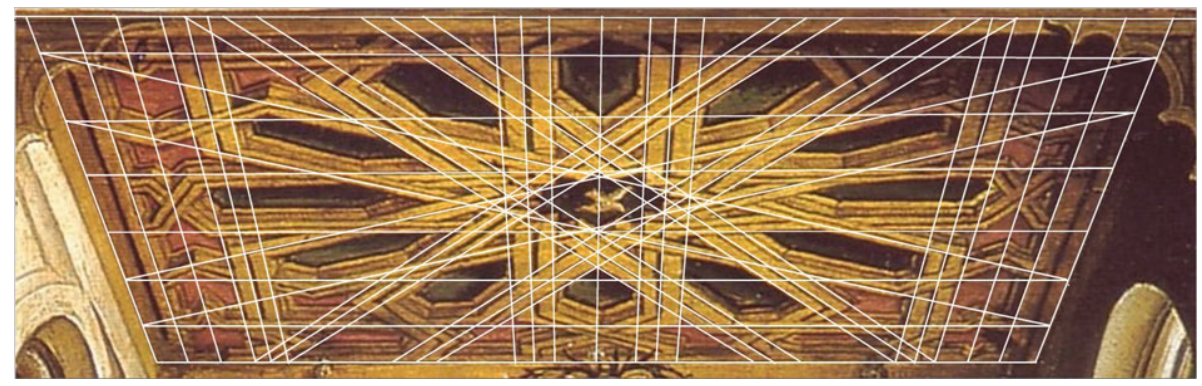

Fig. 6. Analysis of the geometry of the coffered ceiling of the chapel in the panel by Pedro Berruguete

However, geometric analyses of other paintings, without doubt by Berruguete, do not have the characteristics or the high quality of Italian perspective present in works created in Piero's circles. In the panel of the Spanish painter, the inconsistencies in perspective evident in setting up the main volume contrast with a much higher level of precision in the geometric tracing of the Mudejar coffered ceiling (fig. 6). For this reason we feel that the quality of the representation of the ceiling should be attributed to his knowledge of this building technique itself, rather than the hypothetical mastery of specific methods of perspective of Italian art at the end of the fifteenth century. In our interpretation, we take into account the major conceptual difference between the geometry used in construction and that for perspective representation, developed in Italy for visual control of pictorial space.
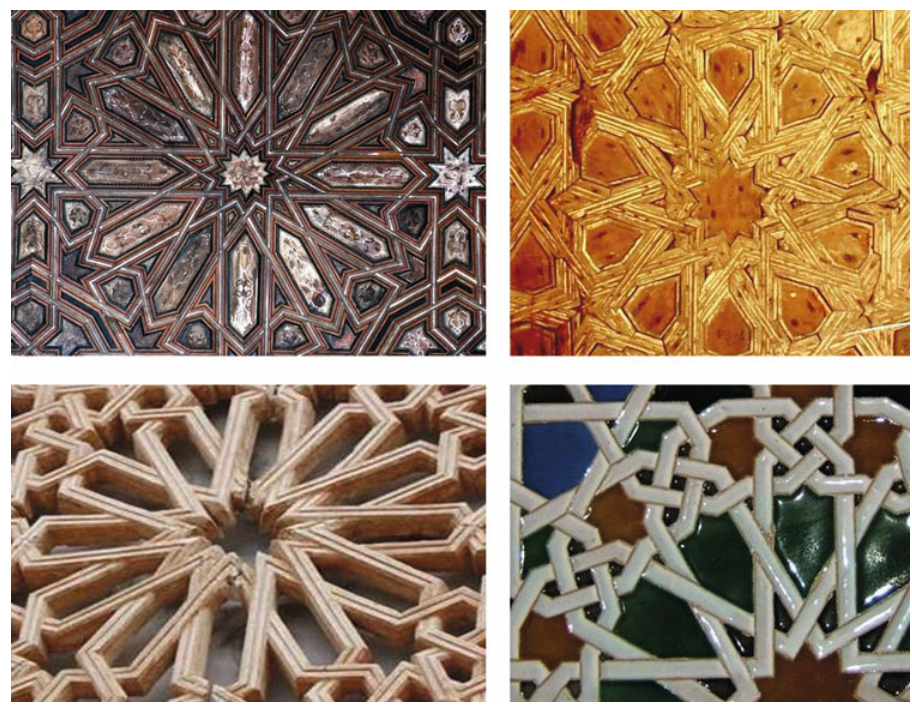

Fig. 7. Design of interlocking lines laid out in a pattern of eight, in different materials and eras 
It is well known that Spanish Mudejar coffered ceilings achieved a technical maturity in the sixteenth century due to the rigorous organisational structure of the professionals. Their geometric techniques, something peculiarly their own, were based on highly sophisticated plans, preserved today in manuscripts and writings. While the wooden structures of the coffered ceiling were considered to be of major quantitative and qualitative importance among these craftsmen, we know that the same geometry was used in other professions and in other materials, such as plaster, stone and ceramics (fig. 7), media that were not alien to the interests and knowledge of artists. Under these circumstances, it is not surprising that paintings such as the panel by Berruguete exist, which include Mudejar ornamentation.

The experience of geometric techniques applied to fretwork had been accumulated over centuries in the heart of the trade guilds, very different from the situation which framed the development of geometric perspective applied by artists early in the Renaissance era, with characteristics much more 'intellectual' in their theoretical formulation. In the case of Berruguete's panel there is a singular phenomenon: the perspective of the coffered ceiling is foreshortened, which means that the method used for painting it was probably not identical to that used by craftsmen to draw up plans for the construction of wooden coffered ceilings.

While the method of drawing is unknown, it seems that the perspective of the coffered ceiling could have been drawn without necessarily using a vanishing point for the main volume: it is possible to limit the geometric tracing of the coffered ceiling to the area occupied in the painting. We tested a hypothesis for drawing the perspective without using a vanishing point, based on a modular structure (fig. 8).

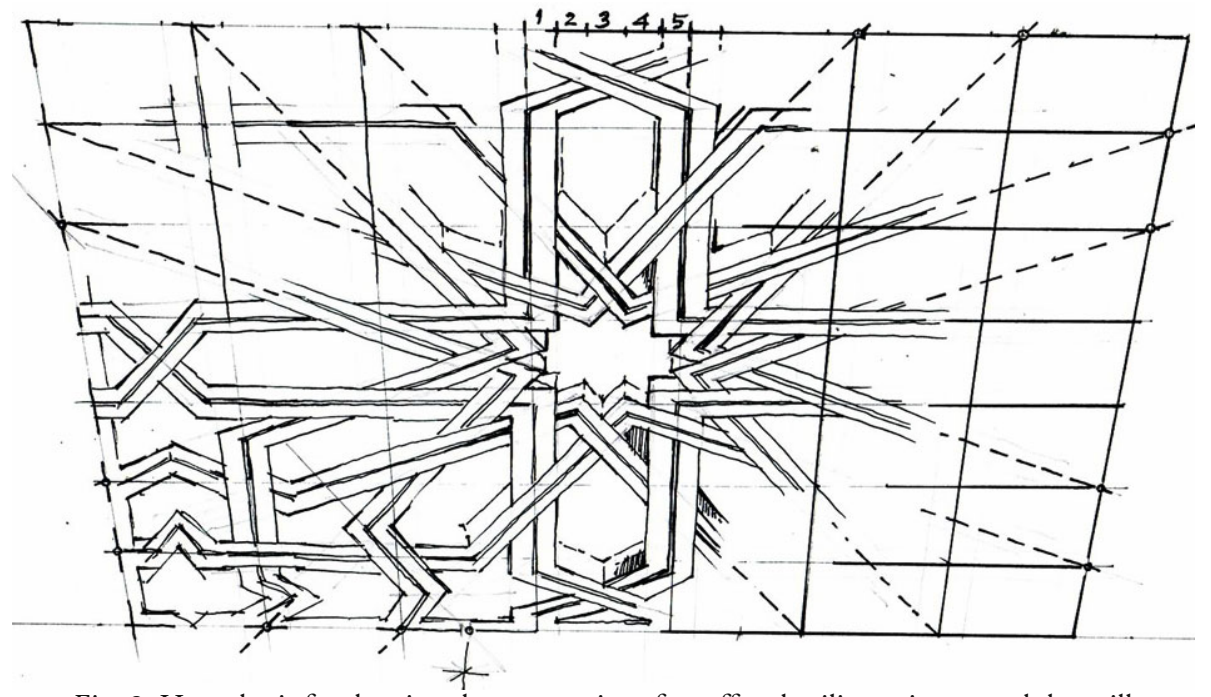

Fig. 8. Hypothesis for drawing the perspective of a coffered ceiling using a modular grill

The preparatory drawings Berruguete is known to have made on some panels, by carving grooves onto the surface to mark the architectural lines, confirm the hypothesis that, on many occasions, the geometry used by artists is basically ornamental, as a filler, and not a spatial or design geometry. Despite this, the final effect is of high quality, demonstrating the painters' capability to synthesise and harmonise very heterogeneous elements to achieve a unitary figurative conception. 
There are antecedents to Gothic panels where the ornamental geometry for filling the background is solved in the same way as in traditional constructions of coffered ceilings, without applying distortions to enhance perspective (fig. 9). Although not much evidence is conserved of the geometric methods used by the professionals, the documents available demonstrate a greater stability and autonomy of craftsmanship, compared to the complexity and constant renovation of methods of perspective.

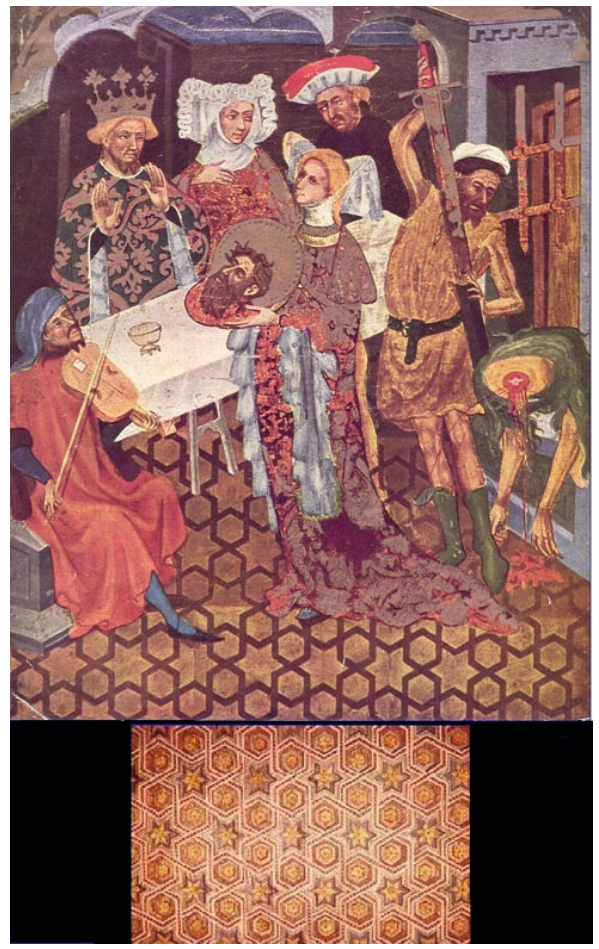

Fig. 9. Gothic panel by unknown author, and Mudejar coffered ceiling with identical interlocking design

Leaving aside the circumstances, the transformations produced during the sixteenth century were major and led to the innovation of formulas to adapt the traditional repertoires of the trades to a new visual conception of architecture and of the arts in general. We know that the highly skilled stonemasons knew how to foreshorten structures such as coffered ceilings. One of the most interesting documents from the century relating to this problem is the Libro de arquitectura, or Book of Architecture, by Hernán Ruiz the Younger, who resolved the challenge of adapting a regular surface of coffers to a trapezoid splayed lintel (fig. 10). On this subject, it should be recognised that, in Spain, development of the geometry was under scientific dominance and the authority of architect-designers.

Thanks to the development of printing, architecture not only attained great prestige due to the actual buildings, but also as a result of the high quality and increasingly precise printed images. An example of this is found in a letter from de Herrera to Cristóbal de Salazar, written when the architect was about to complete works on the Escorial Palace Royal Monastery: "It seemed right to show the whole world a brickwork structure of such great significance" (cited in [Llaguno y Amirola, 1829; our trans.]). 


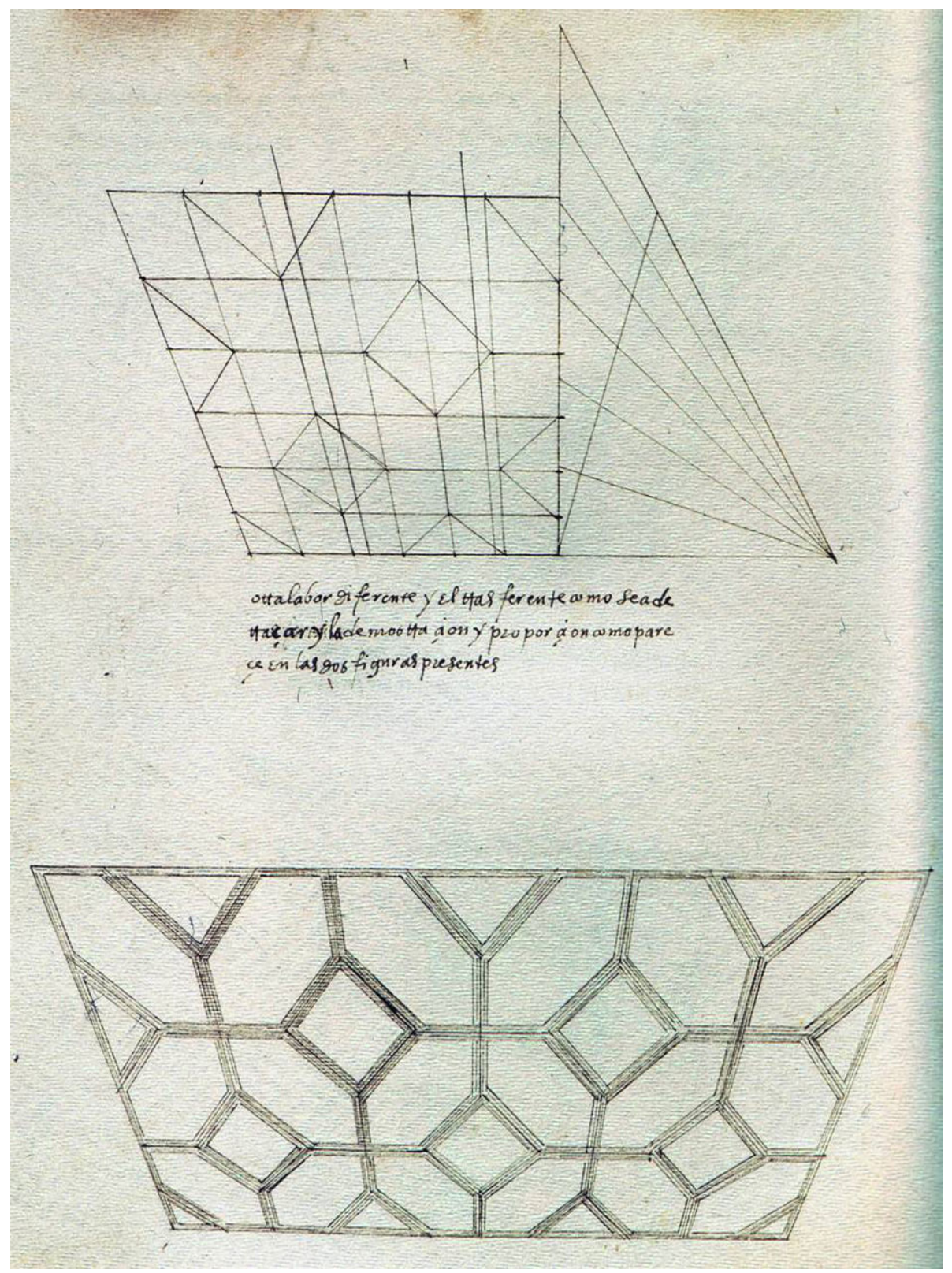

Fig. 10. Hernán Ruiz the Younger, Libro de arquitectura, Treatise on how to draw, present plans and establish proportion

He was referring to the imminent publication of the Sumario y breve declaración de los diseños y estampas de la fábrica de San Lorenzo el Real del Escorial (Summary and brief declaration of the designs and illustrations of the building of San Lorenzo el Real del Escorial) [Herrera 1589], which was illustrated with a famous perspective, or 'scenographia' (fig. 11). 


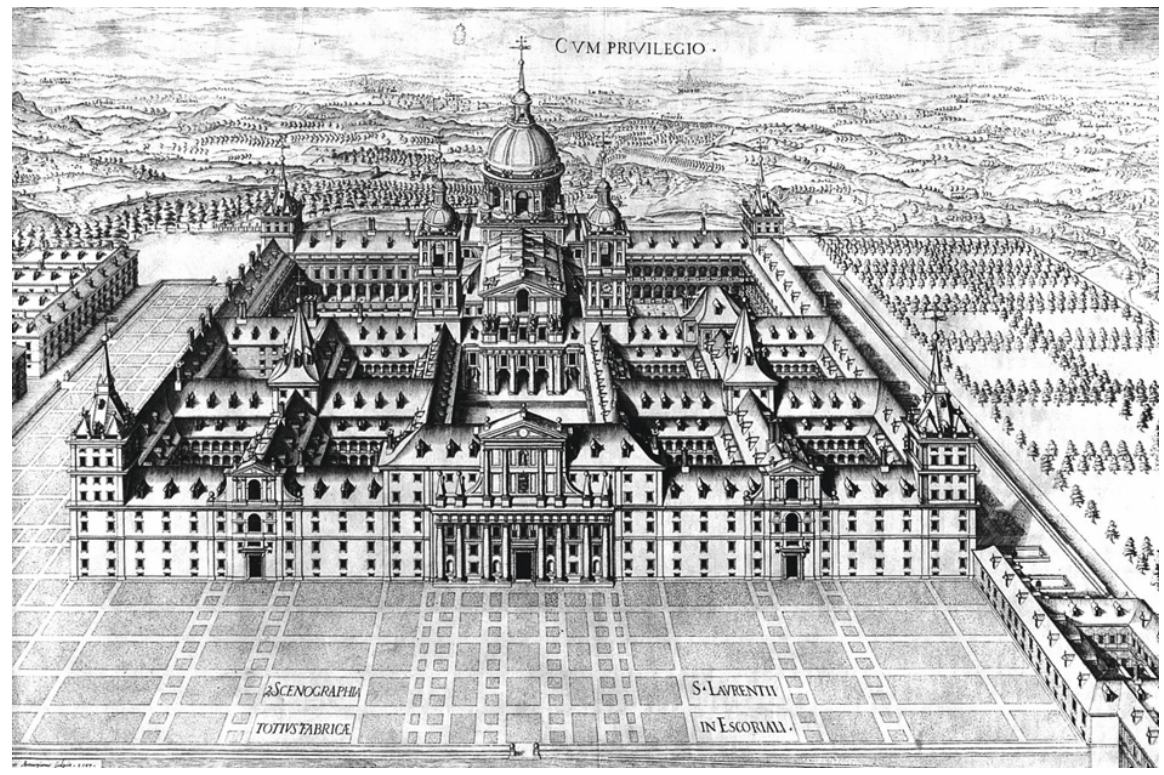

Fig. 11. Juan de Herrera, "Séptimo sello", "Scenographia" of the Escorial Palace Monastery, from Sumario y breve declaración de los diseños... [1589]

However, images of architecture were not limited to representing or demonstrating works already carried out. They also took on the function, increasingly important over time, of projecting new constructions. In both cases, the requirement for graphic rigour and conceptual precision of geometric forms is the reason for the advance in many theories of geometry of form. Little by little, the images which combined tradition and innovation, experience and scientific discovery became the stimulus and starting point for graphic considerations in the new architecture.

The other image we analysed, the engraving by Villalpando, accompanied the most extensive and erudite theoretical discourse in Spain on the relationship between perspective and architecture. This discourse developed specifically in the context of the analysis of Vitruvian graphics for the reconstruction of the Temple of Solomon project recorded by the prophet Ezekiel. Juan Bautista Villalpando refers to this in Ezechielem explanationes et apparatus urbis ac templi Hierosolymitani [Villalpando and Pradi 1596$1604]$.

In this text, what draws attention is the disproportion between the theoretical arguments used, mainly philological and geometric, as well as theological, in contrast to the few arguments based on professional architecture in relation to drawing plans. A fragment of the text demonstrates the difficulties of creating a perspective of the temple due to the high level of scientific requirements, impossible in the everyday work of an architect.

...the perspective demands so much diligence, so much art and work, enough to intimidate many, even the wisest and most learned, so that they give up. Well I, who have spent much of my time carrying out this work, without giving in to fatigue, sparing no costs or effort, from the very beginning, have been dominated by the unique wish to show, among so many graphic reconstructions of the Temple, a perspective of the whole building. I have tried 
to do it many times, but have given up even more often because of the difficulty, the time required, defeated by the delay in completing it. However, I who have not been able to present the perspective of the whole Temple, present here that of its major and most sacred section, namely that of the Holy of Holies, with this inscription: PERSPECTIVE OF THE VAULT OF THE WALLS AND THE PAVING OF THE SANCTA SANTORUM AND OF THE ARC OF THE COVENANT WITH THE CHERUBIM [Villalpando 1990: 166].

The demands Villalpando imposed on his own graphic work become evident when he confesses having tried to draw a perspective of the whole Temple, without being able to finish it, settling for the perspective of the "major and most sacred section": the Holy of Holies, on which we focus our attention. He dedicated more than fifteen years of work before he published this perspective of the whole Temple, never completed. However, after confessing that he had tried but stopped many times because of the difficulties involved, Villalpando adds: "I am not without hope that I will be able to offer the perspective of the whole Temple after giving the final touch to this work, if God gives me the strength and long life" [Villalpando 1990: 166].

There were two challenges for drawing the perspective of the Holy of Holies. First there was the groin vault, formed by the intersection of two cylindrical surfaces, defining two ellipses, whose graphic resolution using a series of points had been perfectly worked out by Piero della Francesca more than a century earlier [Piero della Francesca 1984: 122]. And even though Piero's De prospectiva pingendi was never published, the scheme became well-known through the treatises of others, such as that of Sebastiano Serlio [1545].

The second geometric problem of Villalpando's engraving consists in the construction of the rhomboids on the paving, walls and vault. Nowadays, in contrast to what was known in the sixteenth century, we note geometric 'errors' in the engraving of the Holy of Holies which are easily detectable with present-day knowledge that allows us to distinguish, on the surface, straight generatrices, ellipses and cylindrical helices (fig. 12). All these questions of representation and graphic control of architecture were then resolved intuitively, as in the case of the treatise by Serlio.

When it comes to the 'style' of the rhomboidal coffers which appear in Villalpando's engraving, it is obviously indebted to the monuments of Roman architecture, particularly in one of the niches conserved in the apse of the second-century Temple of Venus and Rome (fig. 13). The engraving was made in Rome around 1594-1595, four years after Villalpando arrived in the city. Roman architecture was a major influence throughout Europe at that time, and specific elements, such as the Roman niche, became well-known thanks to their influence on other constructions and their impact on illustrations in writings such as those of Philibert de l'Orme [1567] and Androuet du Cerceau [15761579]. In these publications, the authors reproduced the Royal Chapel of the Château d'Anet (figs. 14 and 15), the most famous work by de l'Orme, with rhomboid coffers, done after his three-year stay in Rome, where he had, according to Blunt, studied, measured, and even excavated in the Roman ruins [Blunt 1958: 14].

At the time, with the geometric method of design, a complex spatial structure could be represented in two dimensions, such as the vault in the Royal Chapel of the Château d'Anet where the form of the paving is similar to that of the vault, and they can be associated using straight lines perpendicular to the floor. In one of his treatises (fig. 16), de l'Orme acknowledges how proud he is of the geometric method he applied to the project: 


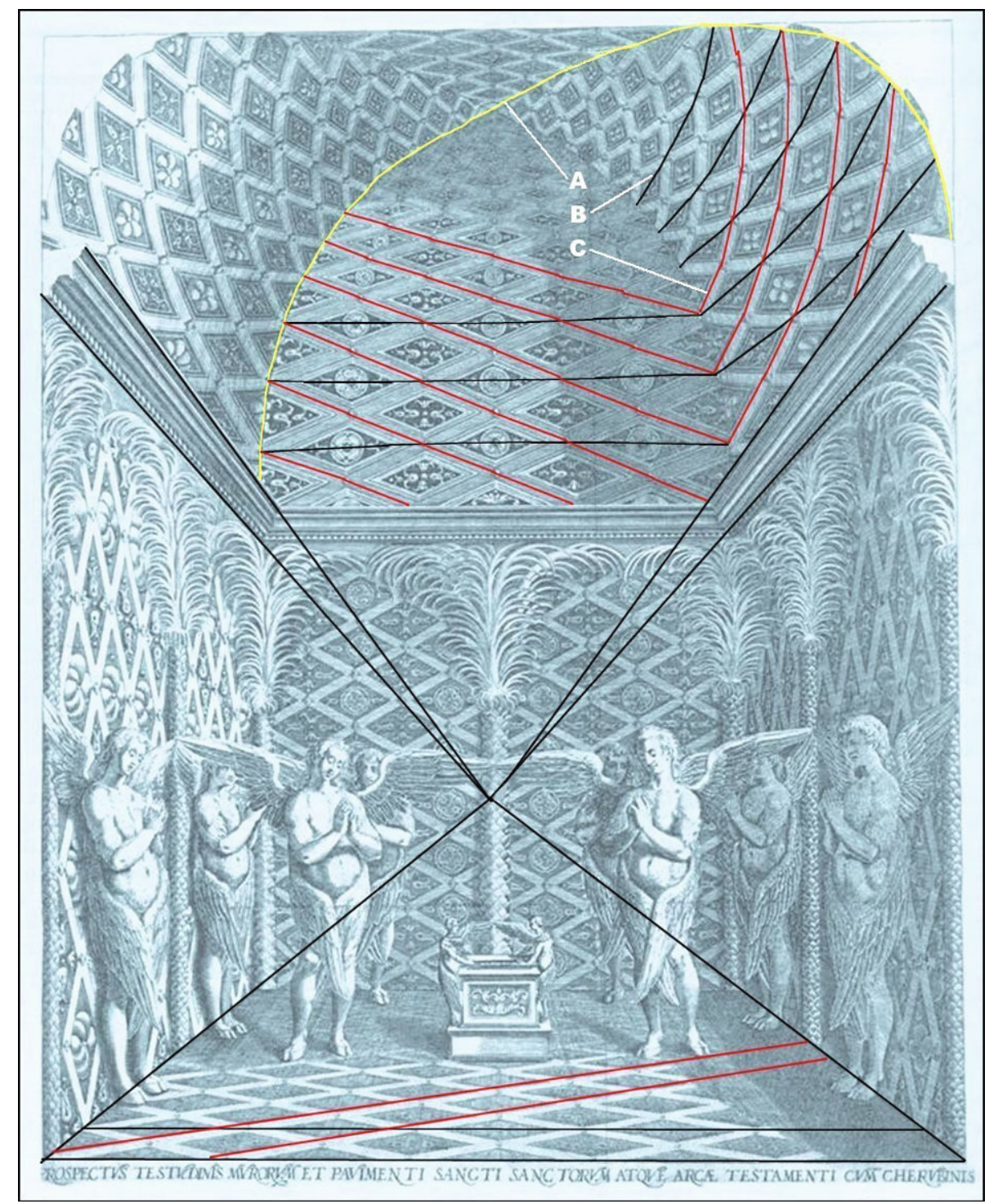

Fig. 12. Theoretical analysis of the lines in the Vilalpando engraving. A: ellipsis, B: straight line, C: cylindrical helix 


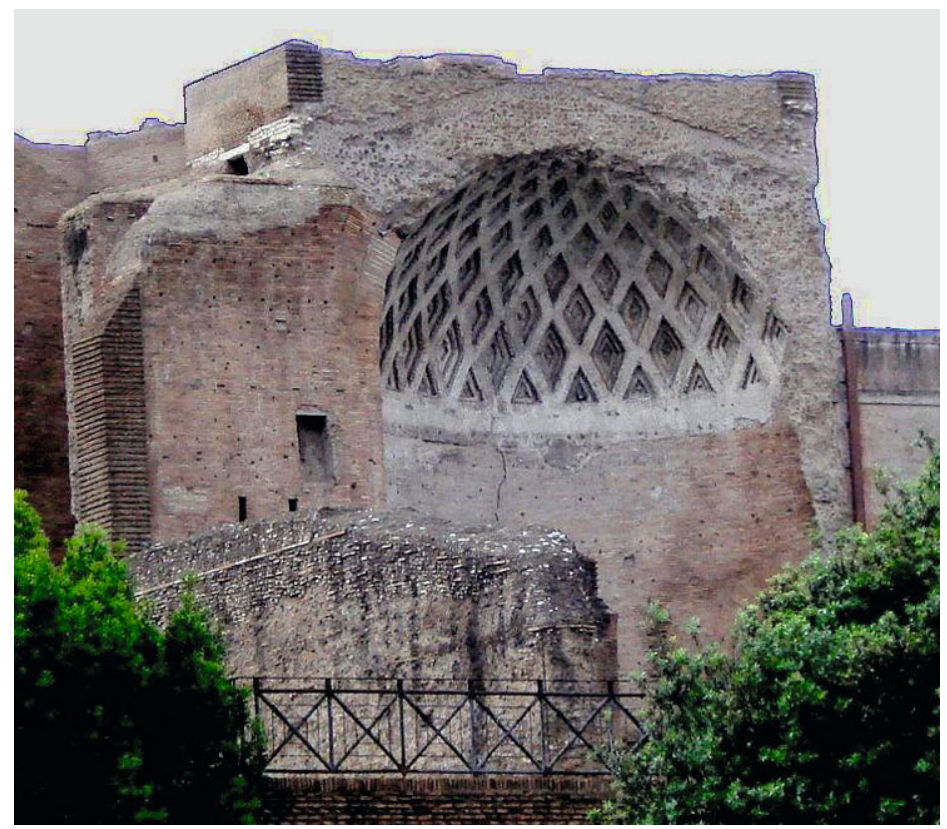

Fig. 13. Apse of the Temple of Venus and Roma, s. II, Rome

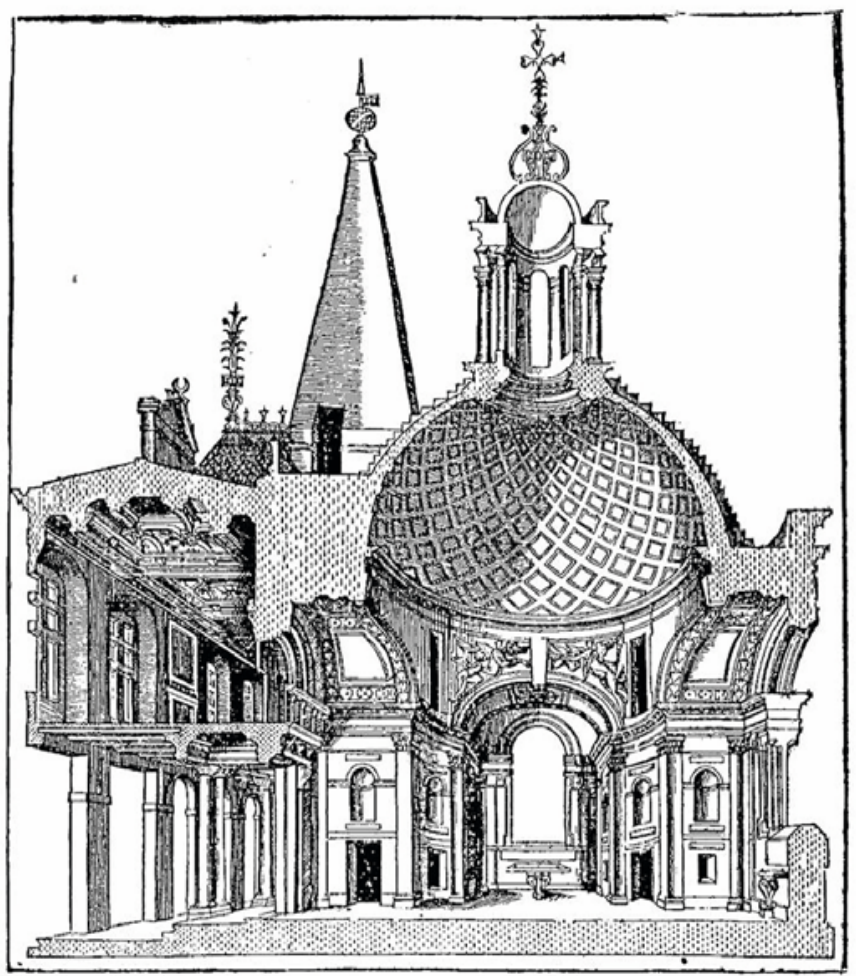

Fig. 14. Philibert de l'Orme, Royal Chapel of Château de Anet, 1567 

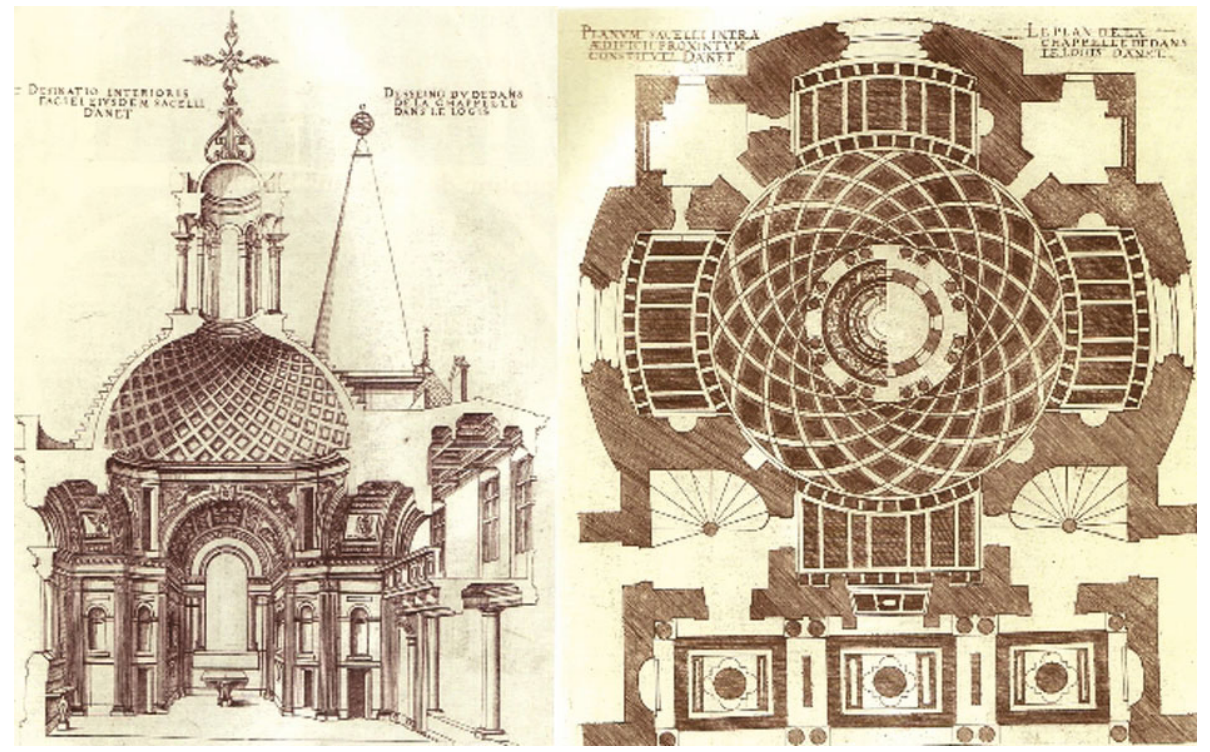

Fig. 15. Androuet du Cerceau, cross section and floor plan of the Royal Chapel of Château de Anet [1576-1579]

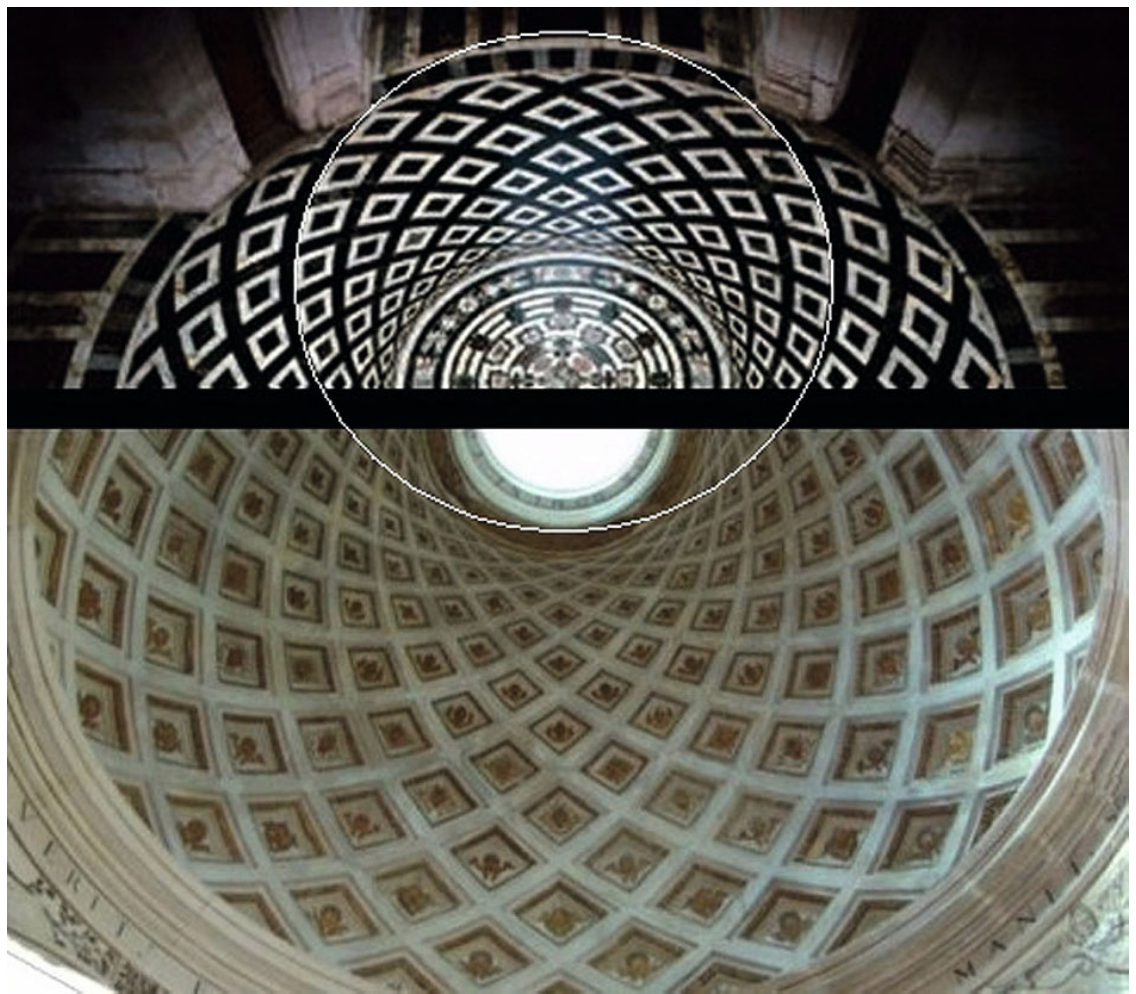

Fig. 16. Comparison of the paving and the vaulted ceiling of the Chatteau de Anet Royal Chapel, designed by Philibert de l'Orme 
Those who take the trouble will know what I did for the dome which I had to build in the chapel of Anet, with various sections arranged in opposing directions. The same system was used to create the coffer design on the floor and the pavement, which correspond through a projection along perpendicular lines. ${ }^{2}$

The maturity and capacity of the graphic systems made it possible to propose new and complex forms which did not necessarily have their origins in practical building experience. In the case of Dürer, in addition to having solid technical knowledge of architecture, his mastery of graphic resources and knowledge of geometry allowed him to generate new forms which could not only be used in architecture, but were also valued as aesthetically pleasing forms (fig. 17). The works of Plato affirm that, in Ancient Greece, geometric shapes were considered beautiful in themselves, as they related to the intelligible world of ideas. This way of thinking explains the existence, in the sixteenth century, of works such as that of the mannerist goldsmith Wentzel Jamnitzer who, obsessed by the symbolic architecture of the universe, created geometric figures of great beauty (fig. 18). The consequence of this aesthetic tradition was to materialise in Baroque, in the work of architects such as Borromini (fig. 19).

Starting in Renaissance, printed images would acquire the status of formal proposals and become collections of models for use by craftsmen. In the case of Viator's treatise, the first publication dedicated to perspective, the author describes the figures as exemples ou inductives de besonger en plus grandes (examples or encouragement to be carried out on a larger scale) [Viator 1505] (fig. 20). However, using an architectural drawing as the base for a painting, another flat image, was different to transferring it to stone or other construction material. In the sixteenth century, the efficiency of stonework was based on technical perfection of the structures, where the classification of elements such as springers, groins and infilling was governed by their mechanical efficiency, with ornamentation playing a complementary role.
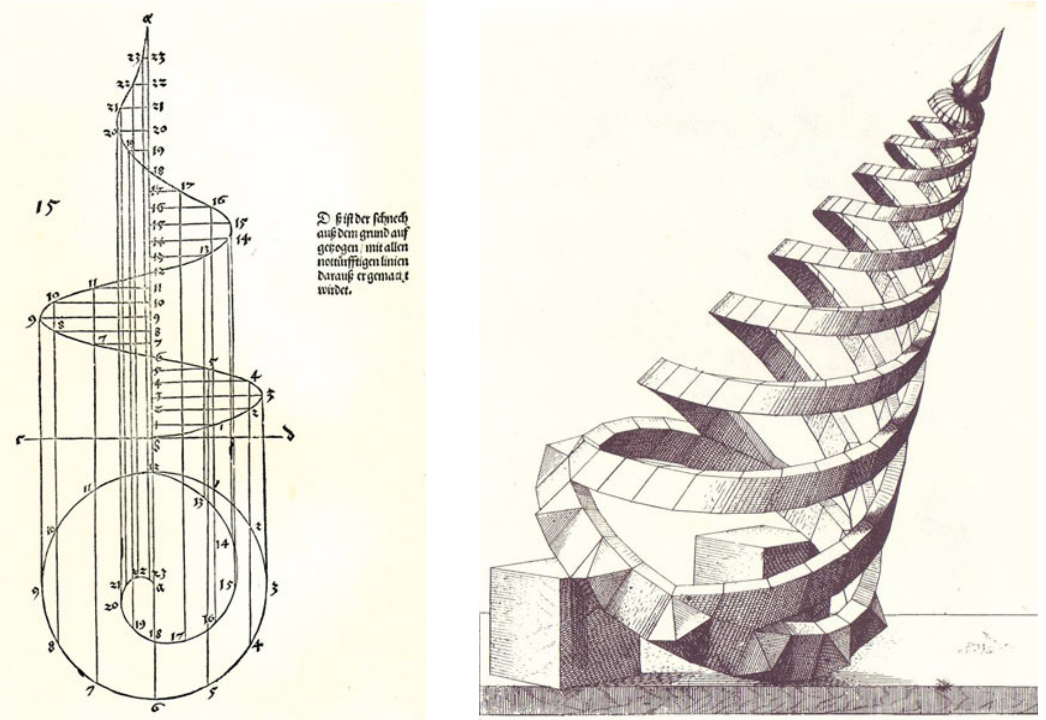

Fig. 17 (left). Albrecht Dürer, conical helix. From his treatise on geometry,

Underweysung der Messung, 1525

Fig. 18 (right). Wentzel Jamnitzer, helicoid. In Perspectiva Corporum Regularium, 1568 


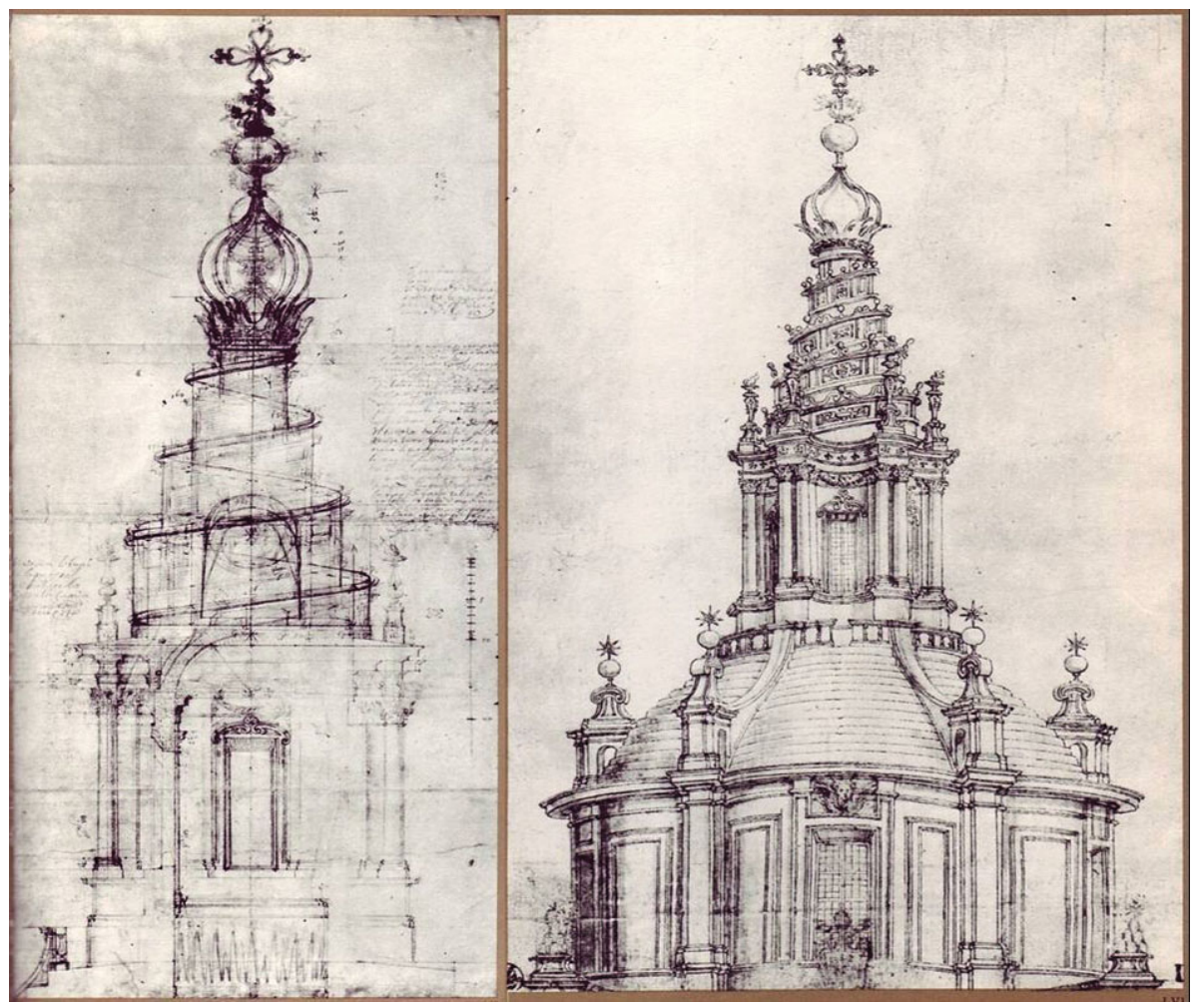

Fig. 19. Borromini, sketches of Sant'Ivo alla Sapienza, 1642-1660

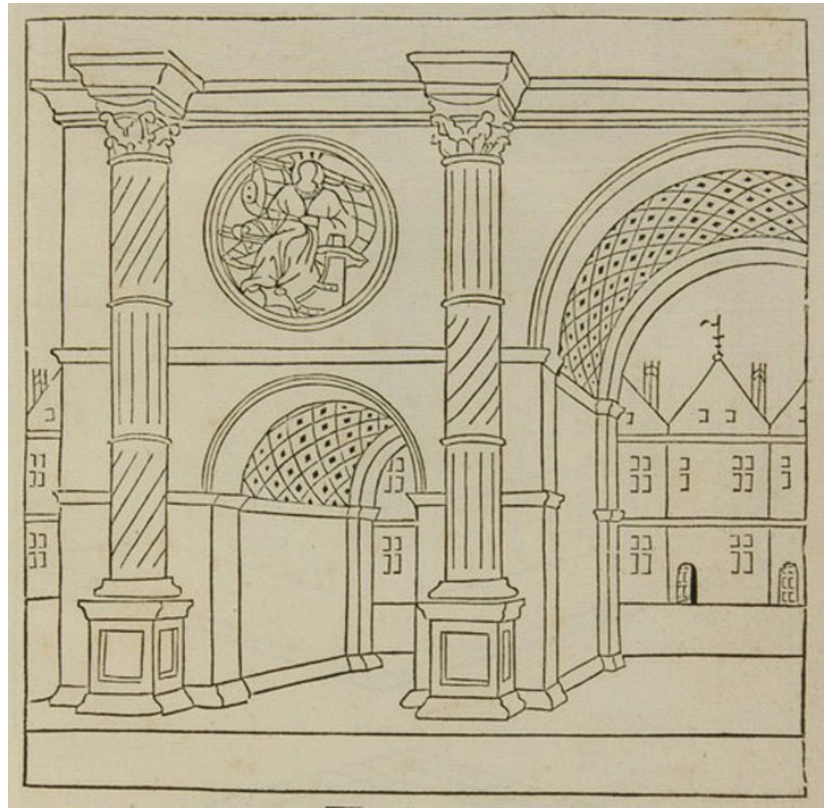

Fig. 20. Viator, Engraving in De artificiali perspectiva, 1505 
On some occasions, the new ornamental repertoires, such as the coffer designs taken from Roman architecture, were adapted to the construction of the masonry structure. A particular example is the vault of the passage to the sacristy in the cathedral in Murcia, with movement generated by a semi-circular structure supported by curved walls. In this vault, each wedge-shaped voussoir of the stone structure coincides with two sunken panels, with very precise contact between structure and ornament, giving the appearance of a coffered surface made up of different pieces, as are the voussoirs (fig. 21).

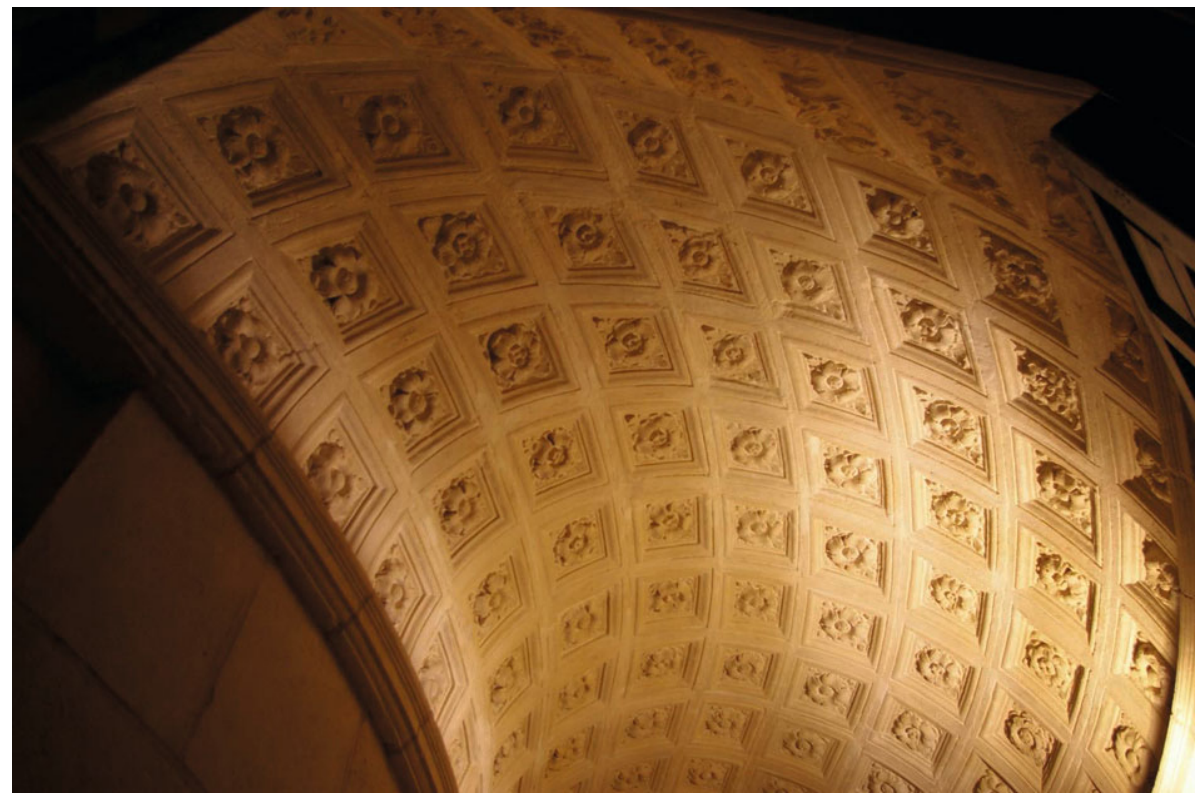

Fig. 21. Coffered vault in the passage of the vestry in the cathedral in Murcia

Contrasting with this unity of structure and ornament, a very obvious separation is present in other constructions. The first theoretical work by Philibert de l'Orme, Le premier Tome de I'Architecture [1561], is a clear example of a treatise dedicated to exclusively structural elements. This was the first French publication on architecture dedicated to construction, particularly to the light wooden structures he invented himself, which did not require large joists (fig. 22). The ornamentation was independent and left to a later phase of construction.

The wooden vaults proposed by de l'Orme were built exactly as he had designed them, both in Europe and abroad. A well-known example is the wooden vaulted ceiling in the Jesuit church in the Argentinean city of Rosario (fig. 23). The visible sides of the wooden elements were decorated in various ornamental styles, often the responsibility of craftsmen other than those involved in the construction.

De l'Orme's interest changed from the purely structural in his first treatise to matters of style and ornamentation in his second, the much more theoretical Premier tome de l'architecture [1567] published six years later. In this, his focus on style led him to add a sixth architectural rule, the 'French' rule, to the five existing principles. This solved a technical problem which prevented monolithic blocks being extracted from French quarries for column shafts and caused them to be built them using smaller blocks. 


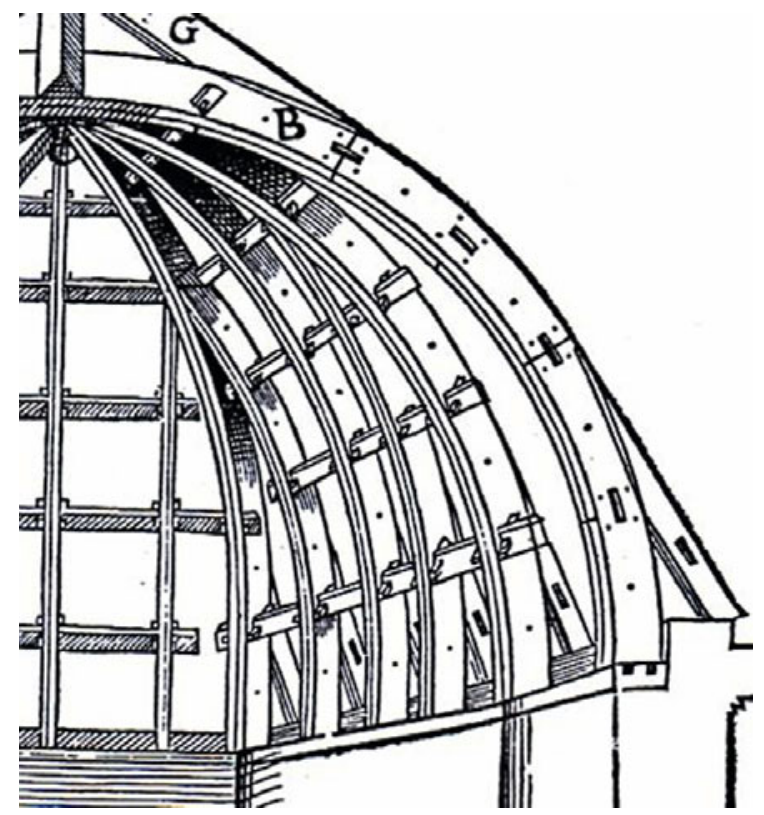

Fig. 22. Wood structure of a vaulted ceiling

from Nouvelles inventions pour bien bastir et a petits fraiz, by Philibert de l'Orme

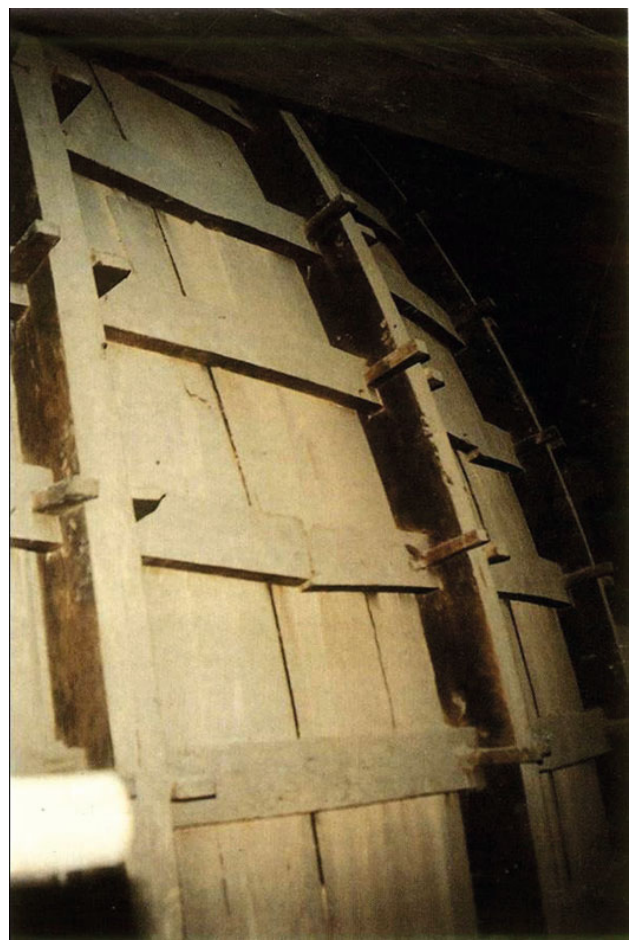

Fig. 23. The upper convex surface of the wooden vaulted ceiling of the Jesuit church in the city of Rosario (Argentina) 
The architect devised tambours with a ring design on the surface to hide the joints in the shaft, thus giving priority to the new style over structural 'truth'. In the following century, giving precedence to innovation over masonry construction techniques was to become more widespread; the Spaniard Juan Andrés Ricci proposed using ornamentation to expressly hide the joints between stones, considering this one of the most important questions in architecture:

One of the most beautiful aspects of architecture is hiding the joints, not only through ashlar masonry where they are set back, but also in the bases and capitals, and with mitre joints, so that joints will not be seen as obviously as they are today, in cornices and other important areas, an appalling thing, meriting repair (cited in [Berchez and Marías 2002, our trans.].

Returning to the case of Villalpando's vaults, we see that, in one of his engravings he uses light wooden structures, in the representation of the section of the Santuario where the suspended vault is hung from the structure, a solution justifiable only for its symbolic value or for the purely ornamental function of its elements (fig. 24).

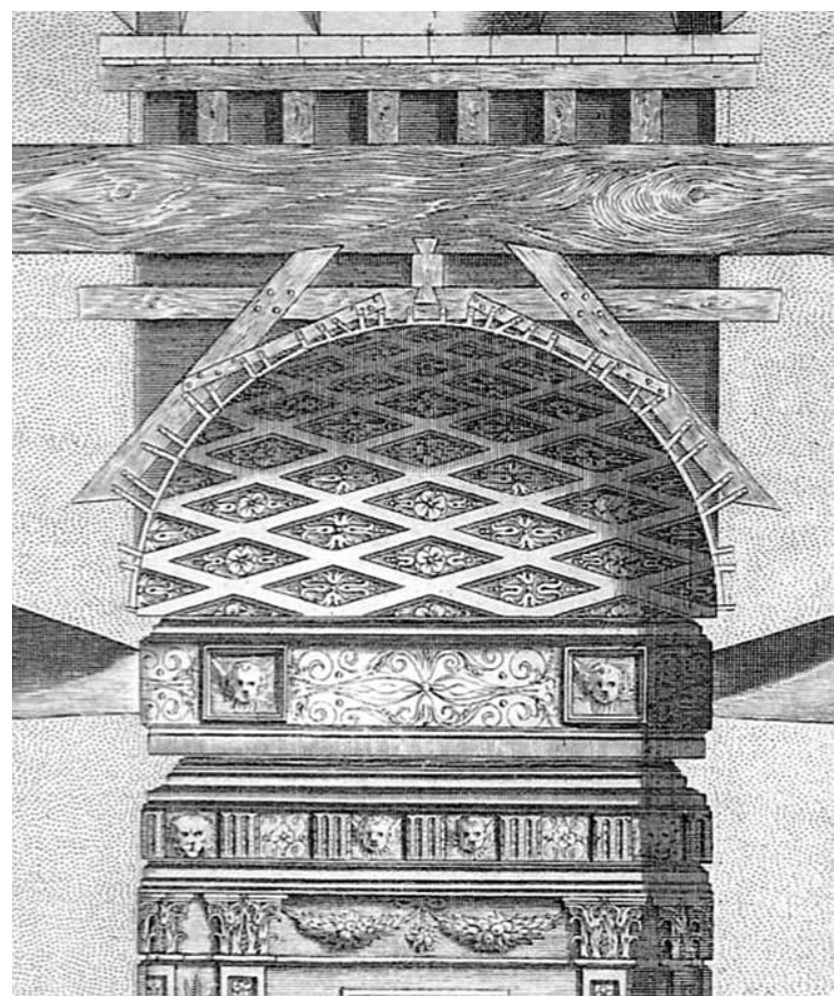

Fig. 24. Juan Bautista Villalpando, section of the Sanctuary with the suspended vault ceiling, 1595

The system of construction was similar to those proposed by de l'Orme in his treatise, wooden vaults which would become generally used in Spain in the seventeenth century. Fray Laurencio de San Nicolás expressly commented on this phenomenon in his excellent treatise on architecture: 
In Spain, particularly in this Court, covering chapels with wooden domes is being introduced, and it is a very safe and strong structure, looking like stone on the outside" [Laurencio of Saint Nicholas 1664: ch. LI, 189; our trans.].

The Spanish name bóvedas encamonadas [false vaults] is used for those made in lightweight materials such as wood or reed, covered with plaster, usually so that ornamentation can be painted on. This technique had a mediaeval background, and a type of covering with structures similar to those of Philibert de l'Orme was being used in Spain. This was based on Mudejar carpentry where it was normal to use a technique called 'ataurejadas', in which the ornamentation was not defined by the elements of the structure itself but as a result of attaching interlaced strips of wood on the wooden panels covering the framework to obtain an interlocking, geometric ornamentation (fig. 25).

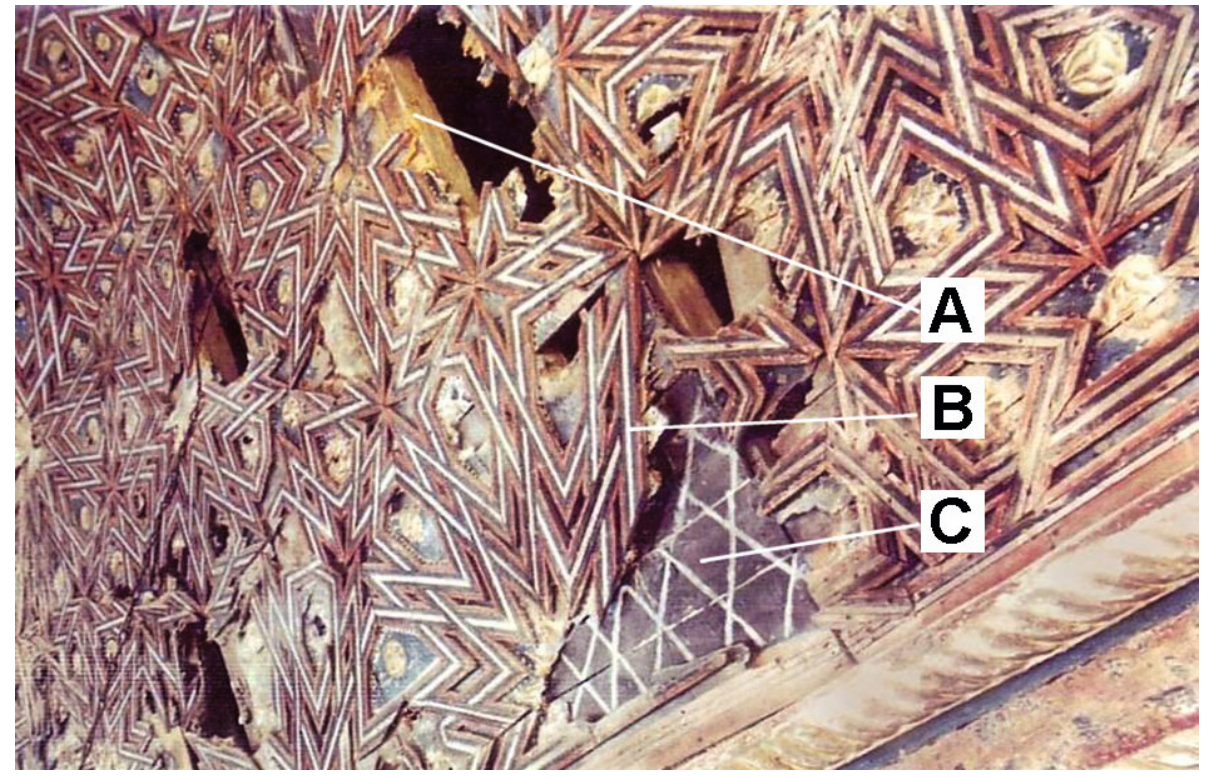

Fig. 25. Detail of the coffered ceiling of Santa Colomba de la Vega (León): A, "pares" (small sloping joists); B, "taujeles” (interlaced carpentry); C, "tablazón” (panelling)

In the professional and stylistic situation of the sixteenth century, the images of Villalpando's work were used, in a theological interpretation, as an instrument to create emotions, or, as the expression of the scientific instrument of Disegno for construction projects. In the vault of the etching of the Sancta Sanctorum it is clear that the ribbing has no structural function but is purely ornamental.

With the invention of perspective geometry, and the science of Disegno in general, the function of images was to design pure forms, often independent of the material factors. This can be seen in a comment by Leonardo da Vinci on a famous drawing in the Codex Atlanticus: "Corpo nato della prospective" (fig. 26). This graphic proposal by Leonardo would be taken up and made their own by later authors, although without it being used directly in construction. Almost eighty years later, we recognise a similar figure in a treatise on perspective by Daniele Barbaro, published in 1569 (fig. 27), and four centuries later another by the artist Escher in one of his famous engravings (fig. 28). 


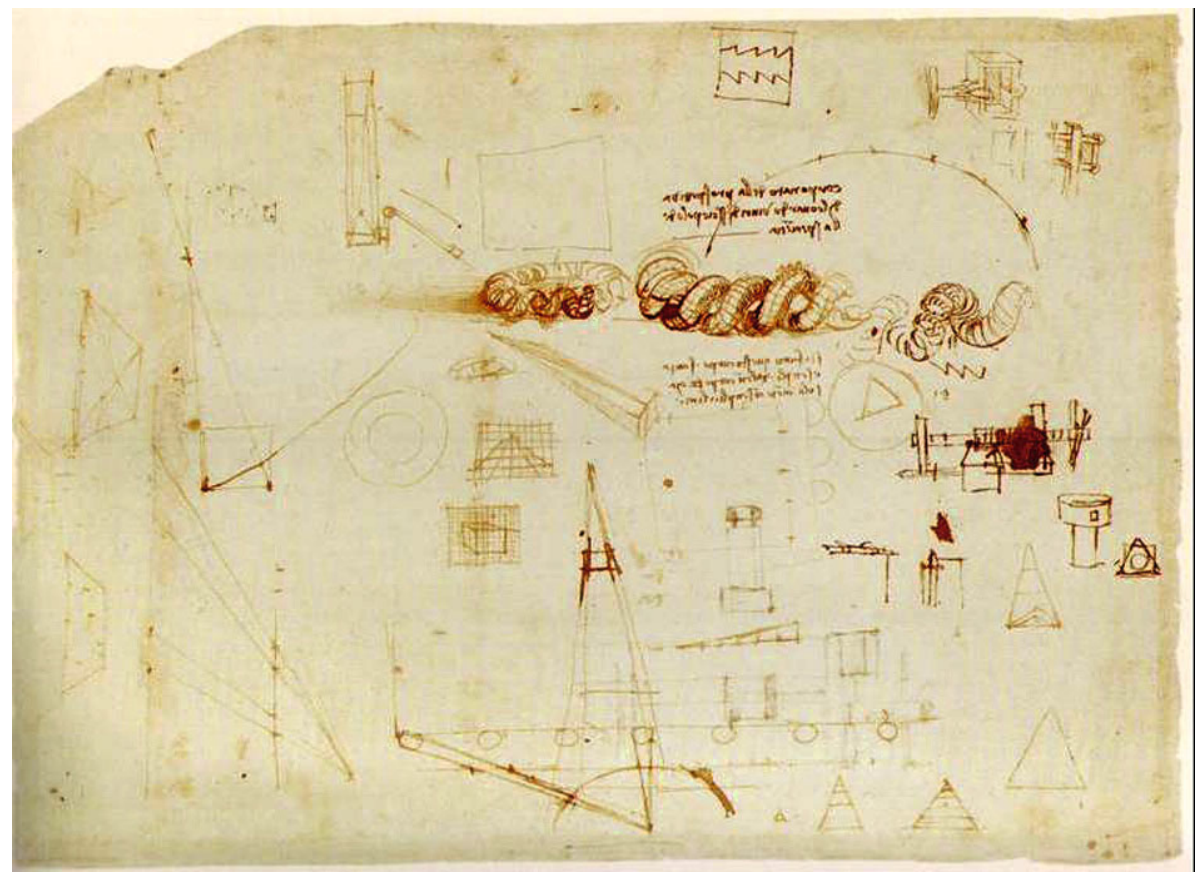

Fig. 26. Leonardo da Vinci, Códice Atlántico, c. 1490: "Corpo nato della Prospettiva"

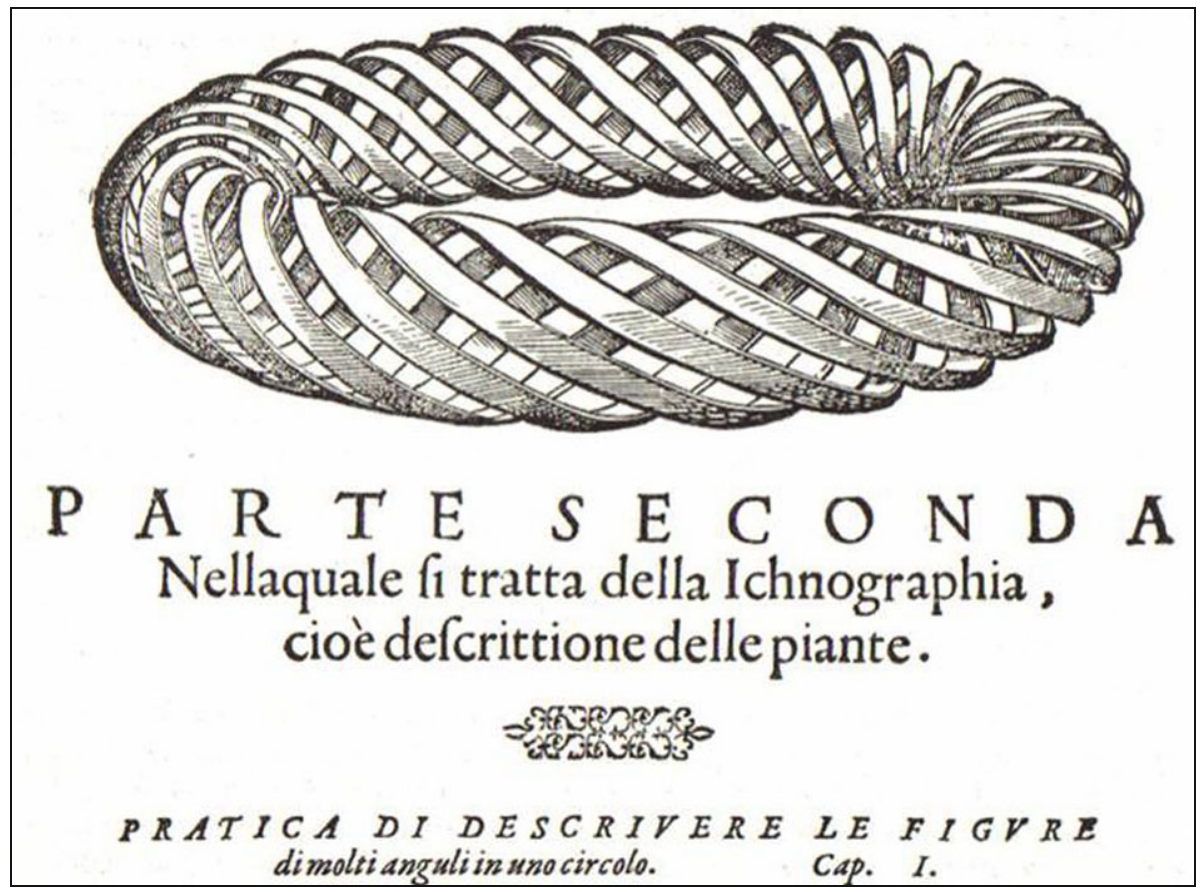

Fig. 27. Daniele Barbaro, La pratica della Perspectiva, 1569 


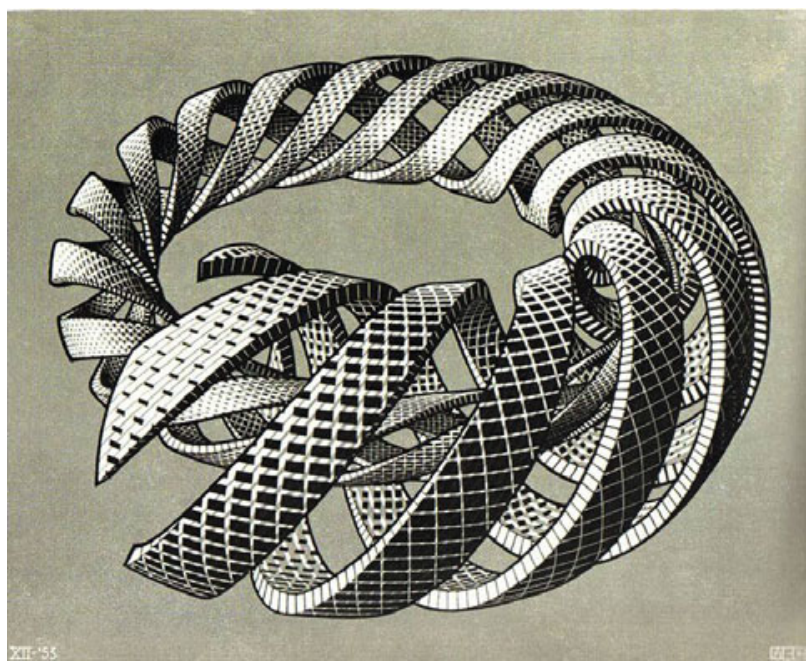

Fig. 28. M.C. Escher, Spirals, 1953
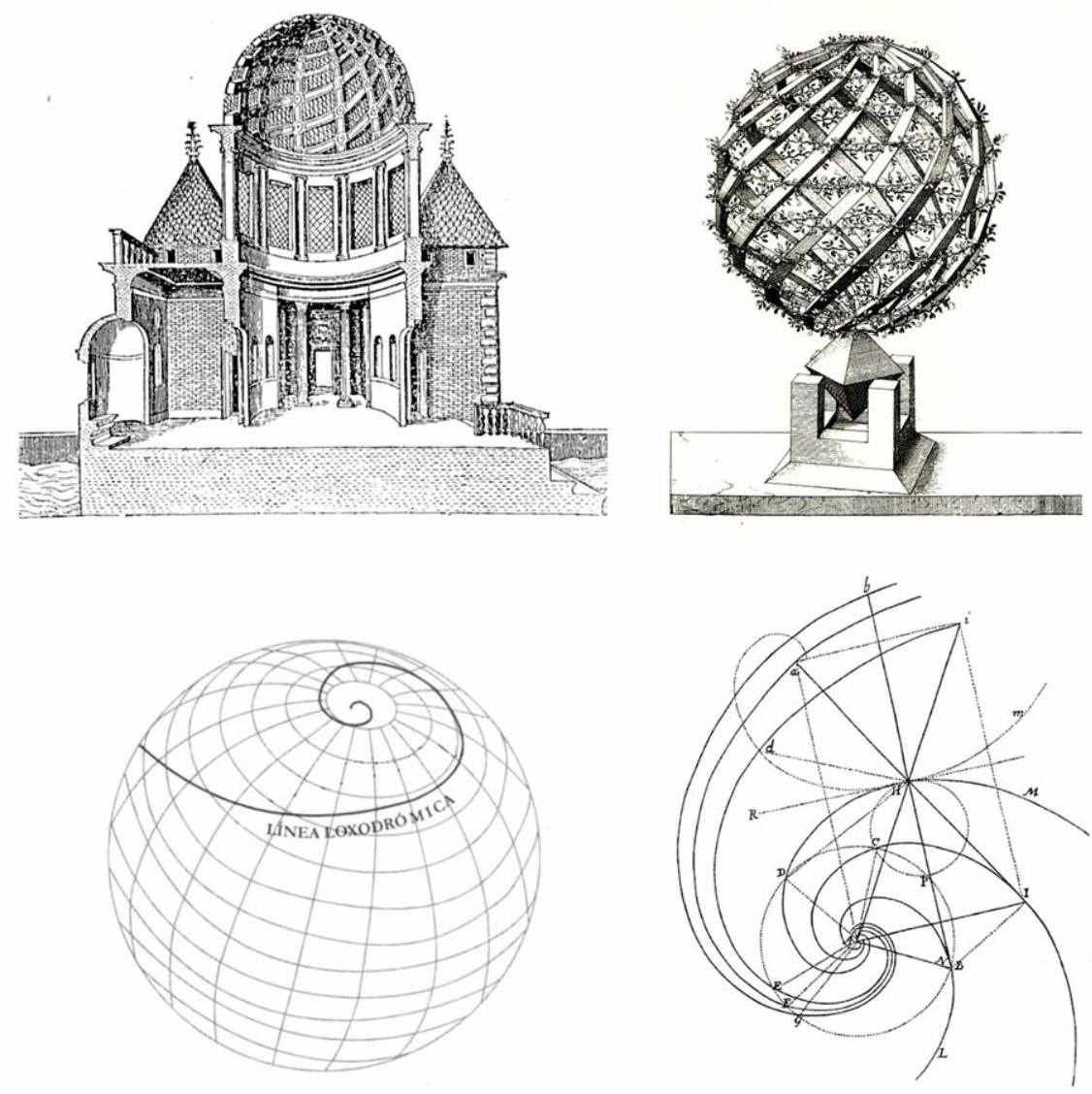

Fig. 29. above, left) De l'Orme, Vault (1561); above, right) Jamnitzer, Perspective (1568); below) loxodrome and logarithmic spiral 
Perspective, as a science of vision, focused on simple forms whose intuitive character was the origin of the consequent scientific rationalisation derived from mathematical thinking. With the geometric figures related to architecture, in the framework of mutual interest, agreements and exchange occurred between practical aspects and the scientific contributions of mathematicians. In this way, the ribs of de l'Orme's vault at the Château d'Anet were projected on the paving as circumferences, being curves in the vault itself, result of the junction of the cylinder projected by the circumferences and the spherical surfaces. While an architect could have resolved this geometry intuitively, we know that this curve was discovered in the fourth century B.C. by the Greek philosopher and mathematician Eudoxus of Cnidus, who called it 'hipopede', horse-fetter, today it is known as the spherical lemniscate.

Over time, geometry has evolved from intuitive control, based on experimentation, to reach scientific maturity in the mathematical field of abstract reasoning. The geometry related to architecture, as for science in general, almost always had certain empirical roots to become established through the formal language of mathematics. Spirals, helices and helicoids, figures perfectly defined by their properties and equations, are good examples of the complex relations between architecture, aesthetics, science and experimentation, matters that go beyond formal similarities.

The overall conception of the culture gives meaning to the obvious relations between the architectural inventions of de l'Orme, the ornamental forms of Jamnitzer, the study of loxodromes as the curves on the Earth's surface, always directed to the same point of the compass, and the logarithmic spiral, which the mathematician Jakob Bernoulli studied around 1694, dedicating a complete book to it (fig. 29).

Translated from Spanish by Shirley Burgess and Michael van Laake

\section{Notes}

1. In 2003, an International symposium, "Pedro Berruguete and his time" was held in Palencia. Many presentations were questioned whether the painter actually spent time in Urbino.

2. Ceux qui voudront pendre la peine, cognoistront ce que ie dy para la voute spérique, laquelle iay faict faire en la Chappelle $d u$ Chasteau dÀnet, avecques plusieurs sortes de branches rempantes au contraire l'un de l'autre, \& faisant par mesme moyen leurs compartiments qui sont a plombe \& perpendicule, dessus le plan \& pavé de ladicte Chappelle [De l'Orme 1567: ch. 11, 122; our trans.].

\section{References}

Berchez, J. and F. Marías. 2002. Fray Juan Andrés Ricci de Guevara e la sua architettura teologica. Annali di architettura 14: 251-279.

Blunt, Anthony. 1958. Philibert de l'Orme. London: A. Zwemmer.

DE L'Orme, Philibert. 1561. Nouvelles inventions pour bien bastir et a petits fraiz. París. . 1567. Le premier Tome de l'Architecture. París.

CERCEAU, Jacques Androuet du. 1576-1579. Le premier volume des plus excellents bastiments de France. París.

DÜRER, Albrecht. 1525. Underweysung der Messung. Nuremberg

Herrera, J. de. 1589. Sumario y breve declaración de los diseños y estampas de la fábrica de San Lorenzo el Real del Escorial. Madrid: Alonso Gómez.

HuYGHe, René. 1965. Diálogo con el arte. Barcelona: Labor.

Llaguno y Amirola, Eugenio. 1829. Noticias de los arquitectos y arquitectura de España desde su restauración. Madrid: Imprenta Real.

Laurencio of Saint Nicholas (Father). 1664. Arte y Uso de Architectura. Madrid. 
MORRISON, Tessa. 2008. Villalpanda's Sacred Architecture in the Light of Isaac Newton's Commentary. Pp. 79-91 in Nexus VII: Architecture and Mathematics, Kim Williams, ed. Torino: Kim Williams Books.

- 2010. Juan Bautista Villalpando and the Nature and Science of Architectural Drawing. Nexus Network Journal 12, 1: 63-73

Piero della Francesca. 1984. De prospectiva pingendi. G. Nicco-Fasola, ed. Florence: Le Lettere.

Sagredo, Diego de. 1526. Medidas del Romano. Toledo: Remón de Petras.

Serlio, Sebastiano. 1545. Libro Secondo, Di Prospettiva. París

ViATOR [Jean Pelerin]. 1505. De artificiali perspectiva. Toul.

Vignola [Jacopo Barozzi]. 1583. Le due regole della prospettiva pratica. Rome.

Villalpando, Juan Bautista, and Jerónimo DEl Prado. 1596-1604. Ezechielem Explanationes et Apparatus Urbis ac Templi Hieroslymitani, 3 vols. Rome.

VillalPando, Juan Bautista. 1990. Juan Bautista Villalpando. El tratado de la arquitectura perfecta en la última vision del profeta Ezequiel. Spanish edition translated from the original Latin by Fray Luciano Rubio O. S. A. Madrid: COAM.

ZEvi, Bruno. 1973. Il linguaggio moderno dell'architettura: Guida al codice anticlassico. Torino: Einaudi. (Spanish translation: El lenguaje moderno de la arquitectura. Barcelona: Poseidón, 1978.)

\section{About the author}

Lino Cabezas Gelabert has a Ph.D. in Fine Arts; currently he is a professor of the Departamento de Dibujo de la Facultad de Bellas Artes de la Universidad de Barcelona. Previously he was professor at the Escuela Técnica Superior de Arquitectura de la Universidad Politécnica de Cataluña. In these institutions he taught classes of perspective, technical drawing and descriptive geometry. He participated and now collaborates in Ph.D and Master couses, conference cycles and meetings organized in several universities and institutions (Fundación Miró, CaixaForum, MUVIM of Valencia, Fundación Juan March, Museo de Arte Abstracto of Cuenca, Museo Arqueológico of Murcia). Among other subjects he published works about the relationship between art and geometry in journals such as D'Art and EGA Revista de Expresión Gráfica Arquitectónica. His latest book is El dibujo como invención. Idear, construir, dibujar (Madrid: Catedra, 2008). 